\title{
Scientology's Legal System
}

Phil Lord

LL.B. (McGill, Dean's List), B.C.L. (McGill, Dean's List), ACIArb.

This paper provides an overview of the legal system of the religion of Scientology. To the members of the religion, this legal system supersedes and fully displaces the mainstream legal system. Scientology's legal system is self-contained and independent, with rules, enforcement mechanisms, and correctional facilities. The overview provided in this paper will be useful to courts and to further research in the nascent yet vital field of Scientological legal research. The contents are as follows: InTRODUCTION; I. SOURCING; II. Within AND WithOUT; III. RULES; IV. ENFORCEMENT MeChanisms; V. CORRECTIONAL FACILITIES; CONCLUSION. 


\section{INTRODUCTION}

This paper provides a broad overview of the legal system of the religion of Scientology. ${ }^{1}$ No legal scholar has yet provided such an overview. This fact is somewhat perplexing, as the religion was founded some seventy years ago. ${ }^{2}$ More broadly, the literature on Scientology is far sparser than that on other recently founded religions such as Jehovah's Witnesses and The Church of Jesus Christ of Latter-day Saints ${ }^{3}$ (two religions which count far more adherents than

\footnotetext{
${ }^{1}$ I am grateful to Prof. Mark Antaki, Alec Sader and Olivier Lirette for their thoughtful comments on earlier drafts. In conducting research for this paper, I have had the opportunity to interact with several Scientologists. The Scientologists who I met at the Montreal and Los Angeles churches have all been kind and helpful. Their passion for and dedication to their religion were evident.

2 James R Lewis, Scientology (Oxford: Oxford University Press, 2009) at 21-23. The exact date of the religion's founding is unclear. The movement finds its roots in the bestseller published by the religion's founder, L. Ron Hubbard, in 1950, Dianetics: The Modern Science of Mental Health (revised ed (Los Angeles: Bridge, 2007) (first published in 1950)). The book introduces many of the concepts which later become central to the religion. It was, however, not originally envisioned as religious scripture. Hubbard thought his experiments would be welcomed by the mental health community. Prior to book's release, associates of Hubbard had unsuccessfully sought to publish papers on Dianetics (and Dianetic therapy, which would later morph into auditing, a key practice of the religion of Scientology) in such outlets as the Journal of the American Medical Association and the American Journal of Psychiatry (see e.g. Russel Miller, Bare-Faced Messiah: The True Story of L. Ron Hubbard (Toronto: Key Porter, 1987) at 151). Approximately one year after the publication of Dianetics: The Modern Science of Mental Health, the New Jersey Board of Medical Examiners began legal proceedings against the Hubbard Dianetic Research Foundation (headquartered in New Jersey) for illegal practice of medicine. The foundation would eventually close its doors due to significant problems with creditors, causing Hubbard to lose control of the trademarks and copyrights associated with Dianetics (see e.g. Miller, ibid at 197-200 and Ronald B Flowers, Religion in Strange Times: The 1960s and 1970s (Macon: Mercer University Press, 1984) at 96-97). In 1952, Hubbard published Scientology, A Religious Philosophy (Christian D von Dehsen, ed, Lives \& Legacies: An Encyclopedia of People Who Changed the World: Philosophers and Religious Leaders (Phoenix: Oryx, 1999) at 90) - the book appears to currently be out of print and be similar to Scientology: The Fundamentals of Thought (L Ron Hubbard (revised ed (Los Angeles: Bridge, 2007) (first published in 1956)). In 1953, he incorporated (again, in New Jersey) the first three churches of Scientology (Miller, ibid at 140-142) - the "Founding Church of Scientology," in Washington, DC, would only be incorporated in 1955 (Douglas E Cowan \& David G Bromley, "The Church of Scientology" in Eugene V Gallagher \& W Michael Ashcraft, eds, Introduction to New and Alternative Religions in America (Wesport CT: Greenwood, 2006) 169 at 172). For academic approaches to the study of Scientology, see generally Roy Wallis, The Road to Total Freedom: A Sociological Analysis of Scientology (New York: Columbia University Press, 1977) and Lewis, ibid.

${ }^{3}$ Both Jehovah's Witnesses and The Church of Jesus Christ of Latter-day Saints were founded in the $19^{\text {th }}$ century, some 100 years before Scientology (Andrew Holden, Jehovah's Witnesses: Portrait of a Contemporary Religious Movement (New York: Routledge, 2002) at 1; Casey Paul Griffiths, Scott C Esplin \& E Vance Randall, “The Glory of God Is Intelligence': Exploring the Foundations of Latter-day Saint Religious Education" (2016) 111:2 Religious Education 153 at 155). Although a 100-year gap in their founding may seem significant, the religions are characterised as new religions as they are significantly younger than more mainstream religions: the founding of the Abrahamic religions (Judaism, Islam, and Christianity) dates back thousands of years ("What Are the Abrahamic Religions?: Christianity, Islam, and Judaism Are Regarded as the Largest Abrahamic Religions by the Number of Adherents", World Atlas, online: <https://www.worldatlas.com/articles/what-are-the-abrahamic-religions.html $>$.)
} 


\section{Scientology). ${ }^{4}$ Only recently has Scientology been studied more extensively in the academy, ${ }^{5}$ notably under the leadership of Dr. Stephen Kent at the University of Alberta. ${ }^{6}$}

\footnotetext{
${ }^{4}$ There are some 15 million members of The Church of Jesus Christ of Latter-day Saints and some 8 million practising Jehovah's Witnesses worldwide ("15 Million Member Milestone Announced at Church's General Conference: President Monson, President Uchtdorf Remark on Church Growth" (5 October 2013), The Church of Jesus Christ of Latter-day Saints: Newsroom, online: <https://www.mormonnewsroom.org/article/15-million-member-milestoneannounced-at-churchs-general-conference> ; "2017 Service Year Report of Jehovah's Witnesses Worldwide: 2017 Grand Totals", Jehovah's Witnesses: Publications, online: <https://www.jw.org/en/publications/books/2017-serviceyear-report/2017-grand-totals/> .) Although Scientology claims membership in the millions (Elaine Jarvik, "Scientology: Church Now Claims More than 8 Million Members" (20 September 2004), Deseret Morning News, online:

$<$ https://web.archive.org/web/20080616032022/http://deseretnews.com/dn/view/0\%2C1249\%2C595091823\%2C00. html> ), more independent sources suggest there are many fewer Scientologists, see e.g. Jonny Jacobsen, "Counting Scientology: Reality Check: Independent Data Contradicts Scientology's Membership Claims" (9 February 2017), Medium, online: <https://medium.com/how-many-scientologists-are-there-really/5-factoring-in-reality$3 \mathrm{f} 0 \mathrm{bb} 2 \mathrm{~d} 4 \mathrm{e} 4 \mathrm{cf}>$ (the latest United States census found some 55,000 self-identifying Scientologists).
}

${ }^{5}$ As an example, Nova Religio (formerly The Journal of Alternative and Emergent Religions) has recently dedicated a full issue to Scientology. The articles in the issue focussed on the confidentiality of high-level Scientology materials (Hugh B Urban, “'The Third Wall of Fire"' (2017) 20:4 Nova Religio: The Journal of Alternative and Emergent Religions 13), on Scientology's anti-psychiatry stance and the work of some of its "front groups" (Donald A. Westbrook, "'The Enemy of My Enemy Is My Friend': Thomas Szasz, the Citizens Commission on Human Rights, and Scientology's Anti-Psychiatric Theology" (2017) 20:4 Nova Religio: The Journal of Alternative and Emergent Religions 37), and on questionable brainwashing techniques which could be attributed to L. Ron Hubbard (Massimo Introvigne, "Did L. Ron Hubbard Believe in Brainwashing?: The Strange Story of the 'Brain-Washing Manual' of 1955" (2017) 20:4 Nova Religio: The Journal of Alternative and Emergent Religions 62). (For more information on Scientology's "front groups," see note 7, below.) Nova Religio was the first journal to dedicate a full issue to the religion.

${ }^{6}$ Kent's research on Scientology is wide-ranging. In one of his first articles, "The Creation of 'Religious' Scientology" (1999) 18:2 Religious Studies and Theology 97, Kent studies how Hubbard came to define Scientology as a religion, arguing that the decision was the result of social and financial pressures. He argues that the adoption of the label helped shield Scientology from increasing scrutiny by medical boards and government agencies. The article is critical of Scientology and of Hubbard's motivations. In "Scientology - Is this a Religion?" (1999) 4:1 Marburg Journal of Religion 1 at 1, Kent again addresses the labelling of Scientology as a religion, concluding as follows:

Although some social scientists insist that Scientology is a religion, the more appropriate position to take is that the organization is a multi-faceted transnational corporation that has religion as only one of its many components. Other components include political aspirations, business ventures, cultural productions, pseudo-medical practices, pseudo-psychiatric claims, and (among its most devoted members who have joined the Sea Organization), an alternative family structure.

Kent has also criticised Hubbard's claims that Scientology "was related to or shared significant similarities with" Eastern Religious Traditions ("Scientology's Relationship with Eastern Religious Traditions" (1996) 11:1 Journal of Contemporary Religion 21 at 21) and Scientology's attacks of psychiatry (Stephen A Kent \& Terra A Manca, "A War Over Mental Health Professionalism: Scientology Versus Psychiatry" (2009) 12 Mental Health Religion \& Culture 1.) He has, finally, considered the various non-religious initiatives coordinated by the Church, see e.g. "The Globalization of Scientology: Influence, Control and Opposition in Transnational Markets" (1999) 29 Religion 147 and "Narconon, Scientology, and the Battle for Legitimacy" (2017) 19:1 Marburg Journal of Religion 1. 
The relative lack of literature on the religion is, arguably, caused by Scientology's litigiousness and commitment to attack its perceived enemies. For example, Scientology's STAND (Scientologists Taking Action Against Discrimination) league dedicates a page on its website to attacking Dr. Kent. The webpage's lead reads as follows:

Stephen Kent is a biased sociologist of religion who adopted the universally debunked theories of psychologist Margaret Singer and sociologist Richard Ofshe of "coercive persuasion" and "brainwashing" as applied to religions and made a career as a paid witness for litigants against new religious movements. In abdicating academic integrity and methodology for pseudoscientific anti-religious vilification, Kent earned the disrespect and ire of professionals in the field. ${ }^{7}$

\footnotetext{
7 "Bigotry \& Hate Exposed: Stephen Kent", STAND League, online: <https://www.standleague.org/bigotry-andhate/exposed/stephen-kent.html $>$. Scientology's legal structure is too complex to concisely describe, and such a description is unnecessary to the furtherance of my argument. There appear to be no external experts who have studied it. Scientology's main entities include the Religious Technology Center (RTC), the Church of Spiritual Technology (CST), and the Church of Scientology International (CSI) (all non-profit corporations). (Although they are non-profit corporations, the organisations pay royalties to a trust related to Hubbard's estate whose beneficiaries are unknown, see Richard Behar, "The Prophet and Profits of Scientology" (27 October 1986), Forbes, online: $<$ https://www.cs.cmu.edu/ dst/Fishman/forbes-behar.html $>$.) The Religious Technology Center controls the trademarks and copyrighted materials associated with Scientology (Jonathan Rosenoer, CyberLaw: the Law of the Internet (New York: Springer, 1996) at 62; "Copyright and Trademark Notice", Scientology, online: $<$ https://www.scientology.org/copyright.html $>$.) These trademarks and materials are owned by the Church of Spiritual Technology, which operates under several names, including L. Ron Hubbard Library ("Copyright and Trademark Notice", ibid.) The Church of Scientology International handles the day-to-day management of the Church ("Frequently Asked Questions: What is Church of Scientology International?", Scientology, online: $<$ https://www.scientology.ca/faq/church-management/what-is-church-of-scientology-international.html $>$.) The Office of Special Affairs, a subsidiary of Church of Scientology International, notably administers the campaigns aimed at former members (see e.g. Joel Sappell \& Robert W Welkos, "On the Offensive Against an Array of Suspected Foes", The Los Angeles Times (29 June 1990), online: <http://www.latimes.com/local/la-scientology062990xstory.html > and Church of Scientology v Fishman and Geertz, 35 F (3d) 570 (9th Cir 2012) (Deposition of Graham E. Berry) [Fishman]). David Miscavige, the religion's leader, is referred to using the title Chairman of The Board Religious Technology Center (COBRTC or COB) (see e.g. "David Miscavige", Religious Technology Center: Holder of the Dianetics and Scientology Trademarks, online: $<\mathrm{http}$ //www.rtc.org/david-miscavige.html $>$ and Joel Sappell \& Robert W Welkos, "The Man in Control", The Los Angeles Times (24 June 1990), online: $<$ http://www.latimes.com/local/la-scientologysideb062490-story.html> .) The Church also "supports" several "global humanitarian initiatives [and] affiliated social betterment programs," including The Truth About Drugs ("the largest nongovernmental drug information and prevention campaign"), United for Human Rights, Volunteer Ministers (Scientologists visiting "major disaster sites"), The Way to Happiness Foundation International (which distributes booklets containing a "moral code"), Applied Scholastics International (study tools), Narconon Drug Rehabilitation Centers, Citizens Commission on Human Rights (whose mission is "to expose and help abolish any and all physically damaging practices in the field of mental health"), Criminon (rehabilitation of criminals), and STAND (see above) (see e.g. "Introduction: Global Humanitarian Initiatives \& Affiliated Social Betterment Programs Supported by the Church of Scientology", Scientology, online: < https://www.scientology.org/how-we-help.html $>$ and "Bigotry \& Hate Exposed: Stephen Kent", ibid.) This structure is what Kent refers to as "a multi-faceted transnational corporation [. . .] [whose] components include political aspirations, business ventures, cultural productions, pseudo-medical practices, pseudo-psychiatric claims" (Kent, "Scientology - Is this a Religion?", supra note 6 at 1.
} 
While I refrain from addressing the specific claims made in this passage, the tone of the passage is indicative of Scientology's commitment to attack its perceived enemies. Academics are rarely attacked, especially with such strong language. These attacks are likely to have caused a chilling effect within the academy, ${ }^{8}$ at least until Scientology's propensity to attack its perceived enemies became better known. Scientology has, indeed, garnered a great deal of attention in recent years, and its behaviour ${ }^{9}$ has been covered (and decried) in national outlets reaching millions of people, such as $\mathrm{CNN}^{10}$ and $\mathrm{A} \& \mathrm{E} .^{11}$ On the latter channel, a television show spanning three seasons has been dedicated to "giv[ing] a voice to victims of the Church of Scientology despite public attempts to discredit them." 12 As Scientology’s propensity to attack its perceived enemies has become better known, the likelihood of third parties believing the assertions made in Scientology's attack

\footnotetext{
${ }^{8}$ See e.g. Stephen Kent, “Scientology's Harassment of Stephen A Kent, September 1997 - November 2001" in Herbert C Northcott, ed, A History of the Department of Sociology at the University of Alberta 61 at 61, online: $<$ https://era.library.ualberta.ca/items/5d96e454-6177-49a4-b3a3-7a9e7a7cbcf1/view/cf9ca389-f480-4e20-ba61cd790f5dc171/01022018_History_of_Dept_Sociology_UAlberta.pdf $>$ and Ruth Graham, "Are Academics Afraid to Study Scientology?" (5 November 2014), JSTOR Daily, online: < https://daily.jstor.org/scholars-on-scientology/> .

${ }^{9}$ Most of the criticism of Scientology, cited throughout this paper, has been of its campaigns against former members. These campaigns are orchestrated by the Office of Special Affairs, a subsidiary of the Church of Scientology International, see Sappell \& Welkos, "On the Offensive Against an Array of Suspected Foes", supra note 7.

${ }^{10}$ In 2010, prominent CNN anchor Anderson Cooper ran a five-part series titled "Scientology: A History of Violence" on his show Anderson Cooper 360. The series was extensively covered in other outlets (see e.g. Joe Nocera, "Scientology's Chilling Effect" (24 February 2015), The New York Times, online: $<$ https://www.nytimes.com/2015/02/24/opinion/joe-nocera-scientologys-chilling-effect.html> and Gillian Grace, "Anderson Cooper to Scientology's David Miscavige: 'It's On"' (28 March 2010), The National Post, online: $<$ https://nationalpost.com/news/anderson-cooper-to-scientologys-david-miscavige-its-on $>$.) It focused on physical abuse within the upper echelons of Scientology.

${ }^{11}$ Television show Leah Remini: Scientology and the Aftermath has run on A\&E channel since 2016 ("Leah Remini: Scientology and the Aftermath: About", $A \& E$, online: $<$ https://www.aetv.com/shows/leah-remini-scientology-andthe-aftermath/about> .) The show's coverage is wide-ranging, notably spanning physical abuses within the upper echelons of the religion, thought control, forced disconnection from family members, and shunning of former members.
}

${ }^{12} A \& E$, supra note 11. 
materials has likely been reduced. The potential impact of the assertions on their target nonetheless remains significant. ${ }^{13}$

Scientology's decision to consistently attack its perceived enemies is deliberate. It provides a fit backdrop for this paper's introduction. The decision is anchored in Scientology's legal system, mandated by the latter's rules. In 1965, L. Ron Hubbard created the Fair Game law. The rule provides guidance on the appropriate way to deal with perceived enemies of Scientology. One who is declared fair game may not "be further protected by the codes and disciplines or the rights of a Scientologist." 14 Hubbard later clarified that the rule extends "to suppressive nonScientology wives and husbands and parents, or other family members or hostile groups or even

\footnotetext{
${ }^{13}$ A prime example of the potentially devastating impact of Scientology's attacks on their target is the case of Paulette Cooper. Cooper is an American author and journalist. She was one of the first journalists to investigate and publicly criticise Scientology. Early on in her career, she published The Scandal of Scientology (New York: Belmont-Tower, 1972), a book highly critical of the religion. Following the book's release, Scientology sued Cooper some nineteen times. Scientology also hired private investigators to follow Ms. Cooper and forged bomb threats against itself (the Church) using Cooper's stationery, with plans for further forged bomb threats against public figures such as Henry Kissinger (see e.g. Steve Cannane \& Brigid Andersen, "How the Church of Scientology Tried to Bring Down Journalist Paulette Cooper, aka Miss Lovely", ABC News (21 December 2016), online: <http://www.abc.net.au/news/2015-0717/how-scientology-tried-to-bring-down-miss-lovely/6627782> and Tony Ortega, The Unbreakable Miss Lovely: How the Church of Scientology Tried to Destroy Paulette Cooper (Kidderminster: Silvertail, 2015))

${ }^{14}$ L Ron Hubbard, "Suppressive Acts - Suppression of Scientology and Scientologists - The Fair Game Law", Hubbard Communications Office Policy Letter, 1 March 1965 [Hubbard, "Fair Game Law 1"]. The Canadian Guide to Uniform Legal Citation does not provide a format to cite documents such as the Hubbard Communications Office Policy Letters. Scientologists, when citing the policy letters, typically use the abbreviation HCO PL, followed by the date of the policy letter, see e.g. "Debbie Cook's Email" (5 March 2013), Scientology Cult: "A Time Comes When Silence is Betrayal", online: $<$ http://www.scientology-cult.com/debbie-cooks-email.html $>$. More information about Cooke can be found in Section V. The creation of a law is merely the process of Hubbard publishing an edict in a policy letter or other document. When Hubbard was alive, these documents would be disseminated to local churches. For example, L Ron Hubbard, "Ethics Protection", Hubbard Communications Office Policy Letter, 1 September 1965 bears the mention "Saint Hill Manor, East Grinstead, Sussex", which means the letter was written at Hubbard's manor in the United Kingdom.
} 
close friends" 15 and to organisations such as governments. ${ }^{16}$ Once one is declared fair game, he may be "deprived of property or injured by any means by any Scientologist without any discipline of the Scientologist" and "tricked, sued or lied to or destroyed." ${ }^{17}$ Although the Church has asserted that the Fair Game law was cancelled, ${ }^{18}$ the assertion is contradicted by the Church's written policies and organisational behaviour. ${ }^{19}$

The Fair Game law therefore explains Scientology's decision to attack its perceived enemies. It explains why the organisation's behaviour is consistent, even in the face of public criticism. Other organisations would likely have altered their practices when faced with negative

\footnotetext{
${ }^{15}$ L Ron Hubbard, "Suppressive Acts - Suppression of Scientology and Scientologists - The Fair Game Law”, Hubbard Communications Office Policy Letter, 23 December 1965 [Hubbard, "Fair Game Law 2"].

${ }^{16}$ Referring to the refusal by the Internal Revenue Service (the United States revenue agency) to grant the founding Church of Scientology non-profit status, Hubbard states, "If the Internal Revenue Service continues to act up or if the FDA does sue we can of course Comm Ev [Committee of Evidence - the enforcement mechanism for Scientology rules, see Section IV, below] them and if found guilty, label and publish them as a Suppressive Group and fair game [them]" (L Ron Hubbard, "Administration Outside Scientology", Hubbard Communications Office Policy Letter, 2 April 1965). The quotation also refers to a potential lawsuit by the United States Food and Drug Administration regarding Scientology's alleged labelling of the E-Meter (a religious artifact used in Scientology auditing) as a medical device capable of curing illnesses (see e.g. Lawrence Wright, Going Clear: Scientology, Hollywood, and the Prison of Belief (New York: Albert A Knopf, 2013) at 90).

${ }^{17}$ L Ron Hubbard, "Penalties for Lower Conditions", Hubbard Communications Office Policy Letter, 18 October 1967. This quotation has been extensively used by the media, see e.g. Richard Leiby, "John Travolta's Alien Notion", The Washington Post (28 November 1999), online: <http://www.washingtonpost.com/wpdyn/content/article/2005/07/06/AR2005070601403.html?nav=rss_metro/religion> and Amelia McDonell-Parry, "5 Things We Learned From 'Scientology and the Aftermath,' Episode 2", Rolling Stone, online: $<\mathrm{https}$ //www.rollingstone.com/tv/tv-news/5-things-we-learned-from-scientology-and-the-aftermath-episode-2$104842 />$.

${ }^{18}$ See e.g. Kent Greenawalt, Religion and the Constitution (Princeton: Princeton University Press, 2008) at 298. The process of cancelling a law is similar to the process of creating one, referred to in note 14. Hubbard simply issues an edict declaring a law to be cancelled.

${ }^{19}$ See Wallis, supra note 2 at 144-45. In "Cancellation of Fair Game", Hubbard Communications Office Policy Letter, 21 October 1968; L. Ron Hubbard states, "The practice of declaring people fair game will cease. Fair game may not appear on any Ethics Order. It causes bad public relations. This does not cancel any policy on the treatment or handling of an SP." As stated in the policy letter, while labelling of the policy may have been eliminated, its substance remains unchanged. On Scientology's use of the policy in litigation, see JP Kumar, “Fair Game': Leveling the Playing Field in Scientology Litigation" (1997) 16:1 Rev Litig 747.
} 
media coverage. ${ }^{20}$ The policy explains why Scientology has not: altering the practice would be inconsistent with the (mandatory) rules of Scientology's legal system.

The Fair Game law is a microcosm of Scientology's legal system. It helps introduce a legal system of significant and unusual magnitude and sophistication, a legal system which aims to be self-contained and independent. Few scholars have studied Scientology, and none have studied its legal system. Scientology, unlike other new religious movements, ${ }^{21}$ has not actively sought to establish a research field concerning itself as a religion, much less has it sought to embed within the field Scientologist scholars to tell its version of the story. (The perspective of Scientologist scholars remains lacking yet necessary to a balanced conversation.) Scientology and its legal system have, thereby, been defined haphazardly and hastily in courts and in the media, by defenders and detractors. Rarely have disinterested parties with the benefit of time participated in this vital process.

Studying Scientology's legal system is important, as, to Scientologists, it supersedes and fully displaces the mainstream ${ }^{22}$ legal system. Through the constitutional protections afforded to freedom of religion, governments give the space religious legal systems need to exist and allow

\footnotetext{
${ }^{20}$ One example is The Church of Jesus Christ of Latter-day Saints, which has altered several of its more controversial doctrines, including its teachings regarding the inferiority of the Black race, when pressured by the media and changing societal attitudes, see e.g. Lester E Bush, Jr, "Mormonism's Negro Doctrine: An Historical Overview" in Lester E Bush, Jr \& Armand L Mauss, eds, Neither White nor Black: Mormon Scholars Confront the Race Issue in a Universal Church (Midvale: Signature Books, 1984) at 70. Public relations professionals generally advise organisations to publicly recognise their shortcomings and implements steps to change their behaviour in the face of negative media coverage, see e.g. Kathy R Fitzpatrick \& Maureen Shubow Rubon, "Public Relations vs. Legal Strategies in Organizational Crisis Decisions”(1995) 21:1 Public Relations Review 21.

${ }^{21}$ The Church of Jesus Christ of Latter-day Saints has, for instance, been highly effective at encouraging the production and dissemination of academic research. The Church has "founded, supported, and guided" Brigham Young University, a prominent private research university in the United States ("Missions \& Aims of BYU", BYU, online: $<$ http://aims.byu.edu/> .) There are numerous prominent, peer-reviewed academic publications in the field of Mormon studies, notably Dialogue: A Journal of Mormon Thought and the International Journal of Mormon Studies. Academic research has, undoubtedly, supported the emergence of The Church of Jesus Christ of Latter-day Saints as a mainstream - at least mainstream-like - religion, especially as academics such as Nathan Oman have been appointed at prestigious research universities beyond Brigham Young University.

${ }^{22}$ I use the phrase "mainstream legal system" throughout this paper to refer to the state legal system in jurisdictions where Scientology operates. The phrase is nonspecific and is not limited to the Canadian or American legal systems. For examples of other authors using the same phrase, see Marylin Holly, "Navajo Criminal Justice: A Jungian Perspective" in Jeffrey Ian Ross \& Larry Allen Gould, eds, Native Americans and the Criminal Justice System (Boulder: Paradigm, 2006) 17 at 28 and Estefanía Estéveza, Marina Rachitskiyb \& Carla Rodríguez, "Is Perception of the Mainstream Legal System Homogeneous Across Ethnic Groups?” (2013) 5:2 European Journal of Psychology Applied to Legal Context 155.
} 
members of religious groups to act in a way which is consistent with their beliefs - including the rules and their enforcement mechanisms set out in religious legal systems.

This paper will provide neither an in-depth nor a full critical analysis of Scientology's legal system. It will, rather, provide a broad overview of it, which will be useful to further research in the nascent yet vital field of Scientological legal research and to courts in various jurisdictions. Courts have, indeed, thus far understandably struggled to comprehend Scientology's legal system. They have not benefitted from an objective overview of Scientology's legal system: they have been in the unenviable position of having to rely on two competing, interested positions - that of the plaintiffs and the defendants - to draw an understanding of even the most basic facts regarding Scientology and its legal system.

For the purposes of this paper, I divide the legal system into what I consider to be its three building blocks: rules, enforcement mechanisms, and punishment facilities. Section III, IV, and V each explore one of these building blocks. Beforehand, I address, in Section I, the materials which constitute Scientology's legal system and, in Section II, the way in which Scientology exists as an independent legal system.

\section{SOURCING}

The introduction provided the example of the Fair Game law. I will use this example throughout the paper as a microcosm of Scientology's rules and legal system. The last section also introduced the relative lack of literature on Scientology. It hypothesised Scientology's combativeness and litigiousness as a one of the causes for this lack of literature. As this section will suggest, a further cause may be the complexity of Scientology's doctrinal system. There are, indeed, countless pages of scriptures written by Scientology founder L. Ron Hubbard, ${ }^{23}$ and I

\footnotetext{
${ }^{23}$ The Church claims that "L. Ron Hubbard's works on Dianetics and Scientology comprise the largest cohesive statement on the human mind and spirit-more than 5,000 writings and 3,000 recorded lectures" ("L. Ron Hubbard: Founder of Dianetics and Scientology", Scientology, online: <https://www.scientology.org/l-ron-hubbard/> .) The confidentiality of some Scientology scripture prevents independent verification of this claim. I further address the confidentiality of certain Scientology materials later in this section.
} 
contend that the vast majority of public Scientologists will not have read the totality of these scriptures in their lifetime. I have personally had to spend more than 1,500 hours studying Scientology to gain a basic understanding of its doctrinal system. The complexity of Scientology's doctrinal system may also have caused courts to misunderstand Scientology doctrine. ${ }^{24}$ No roadmap of Scientology sources has been provided by the Church or by an independent third party.

A foundational block of Scientology's legal system is its publicly available materials. These include the "basics books and lectures," a collection of 18 books and 280 lectures. ${ }^{25}$ The books and lectures can be purchased from the Church's publishing arm, Bridge Publications, at a local church or online, by members and non-members. While every scientologist in good standing is expected to acquire this set of books and lectures, ${ }^{26}$ reading the books and listening to the lectures

\footnotetext{
${ }^{24}$ There are countless court cases involving Scientology around the world. A full review of the jurisprudence is beyond the scope of this paper but should be done in further research. In Canada, there have been two seminal cases. In Hill $v$ Church of Scientology of Toronto, [1995] 2 SCR 1130, 126 DLR (4th) 129, the Supreme Court awarded the largest libel award in history after finding that Scientology had publicly made numerous inaccurate allegations against a crown prosecutor. In $R v$ Church of Scientology of Toronto (1997), 33 OR (3d) 65, 34 WCB (2d) 453 (CA), the church was convicted for infiltrating the Ontario government. The case is related to Operation Snow White, where the church infiltrated various agencies of the United States government to destroy unfavorable documents, see Hugh B Urban, "Fair Game: Secrecy, Security, and the Church of Scientology in Cold War America" (2006) 74:2 Religion and Secrecy 356. The church has repeatedly sued former members, see e.g. Church of Scientology v Armstrong, 232 Cal (3d) 1060 (App Ct 1991). The church has also been sued successfully by former members, see e.g. Wollersheim $v$ Church of Scientology, 212 Cal (3d) 872 (App Ct 1989). The most consequential case on Scientology is arguably Fishman, supra note 7 , as the case caused the public disclosure of confidential Scientology materials, including the operating thetan levels (for more on the levels, see note 27, below). While the case did not enter these documents into the public record, some individuals have posted them on the Internet, see e.g. Religious Technology Center v Lerma, 908 F Supp 1353 (ED Va 1995) and Religious Technology Center v Netcom On-Line Communication Services, 907 F Supp 1361 (ND Cal 1995). See also generally Paul Horwitz, "Scientology in Court: A Comparative Analysis and Some Thoughts on Selected Issues in Law and Religion" (1997) 47:1 DePaul L Rev 85.

${ }^{25}$ See e.g. "David Miscavige: Scientology Scripture Recovered and Restored in 25-Year Program Completed in 2009", Scientology, online: <https://www.scientology.org/david-miscavige/renaissance-for-scientology/completion-of-thegolden-age-of-knowledge.html $>$.

${ }^{26}$ Thomas C Tobin, "Pervasive Pitch: Scientology Book and Lecture Series, 'The Basics,' Unleashes a Sales Frenzy", The Tampa Bay Times (13 November 2011), online: < https://www.tampabay.com/news/scientology/pervasive-pitchscientology-book-and-lecture-series-the-basics-unleashes-a/1201177> .
} 
does not count toward progress on Scientology's path to spiritual fulfilment, the "Bridge to Total Freedom."27

Of particular interest for this paper are the books which lay out the policies, rules, enforcement mechanisms, and correctional facilities that define Scientology's legal system. The first and perhaps most relevant such book is Introduction to Scientology Ethics, ${ }^{28}$ one of the basics books. At 393 pages, the book is relatively short. It lays out a basic yet wide-ranging description of Scientology's legal system. The book's foreword accurately describes the book's position relative to other Scientology materials, stating:

Scientologists and, indeed, the whole of Mankind are extremely fortunate to have, for the first time in history, a practical system of Ethics and Justice based solely on reason.

[...]

The new edition of Introduction to Scientology Ethics contains all one needs to effectively use Ethics Technology in one's daily existence. This $i s$ the basic Ethics Handbook. And with it, one can honestly reverse any deteriorating trend.

While data and technology concerning Suppressive Persons and Potential Trouble Sources is contained in this volume, the entire wealth of this technology is only to be found in various PTS/SP Courses that include all Bulletins, Policy Letter and lectures on the subject.

Additionally, while this volume provides the fundamentals of Ethics for application to one's own post and life, the Hubbard Ethics and Justice Specialist Course

\footnotetext{
${ }^{27}$ See e.g. "The Basics", Bridge Publications, online: <http://www.bridgepub.com/introduction/the-basics.html> , where the Church states that "[t]he Basics Books and Lectures form the foundation upon which The Bridge to Freedom is built" [emphasis added]. The structure of the Bridge to Total Freedom is extremely complex. Printed, it covers an entire wall. Its basic structure consists of two sides: auditing and processing. Processing is the process through which the Scientologist progresses to attain spiritual freedom. Auditing is the process of auditing (Scientology counselling) other Scientologists on the same path (see e.g. "Frequently Asked Questions: What Is The Bridge In Scientology?", Scientology, online: <https://www.scientology.ca/faq/background-and-basic-principles/what-is-the-bridge-inscientology.html>.) The first major milestone in auditing is the state of clear which "describes a being who no longer has his own reactive mind, the hidden source of irrational behavior, unreasonable fears, upsets and insecurities" ("Frequently Asked Questions: What Is the State of Clear?", Scientology, online: $<$ https://www.scientology.ca/faq/clear/what-is-the-state-of-clear.html $>$.) Following the state of clear are the operating thetan levels, where Scientologists learn to be able to "handle things without having to use a body of physical means" ("Frequently Asked Questions: What Is Meant by Operating Thetan?", Scientology, online: $<$ https://www.scientology.ca/faq/operating-thetan/what-is-ot.html> .) These levels are confidential. The following link of a picture of the Bridge appears to be an official Scientology source: "The Bridge to Total Freedom", online: $<$ http://www.whatisscientology.org/html/Part02/Chp06/img/grdchart.gif> .

${ }^{28}$ L Ron Hubbard, revised ed (Los Angeles: Bridge, 2007) (first published in 1968).
} 
contains the complete body of technology and is required training for Ethics Officers in Church Organizations. ${ }^{29}$

I, once again, refrain from addressing the substantive claims - such as the claim that Scientology's legal system is "for the first time in history, a practical system of Ethics and Justice based solely on reason." 30 This book is publicly available, and its language is, therefore, more accessible than that of other Scientology materials. Scientology-specific language is nonetheless found throughout the text, indicating the complexity and sophistication of Scientology's legal system: "technology" (which, broadly, refers to Scientology concepts and processes), "suppressive persons," "potential trouble sources" (both defined in Section III), and so forth.

As stated in the passage, the book only provides a broad overview of Scientology's legal system. It is sufficient to providing basic guidance regarding one's actions and decisions but does not provide the full apparatus of rules, enforcement mechanisms, and correctional facilities necessary to fully govern individual and group behaviour - independently of the mainstream legal system, as will be explored in the next section. One must, to do the latter, refer to more advanced materials. The example of the Fair Game law illustrates this point. The law is only briefly alluded to in Introduction to Scientology Ethics. Chapter 12 states:

Due to the extreme urgency of our mission, I [L. Ron Hubbard] have worked to remove some of the fundamental barriers from our progress.

The chief stumbling block, huge above all others, is the upset we have with Potential Trouble Sources and their relationship to Suppressive Persons or Groups.

$[\ldots]$

This material gives the means and provides the policy for getting the above situation handled.

$[\ldots]$

Suppressive Persons or Groups relinquish their rights as Scientologists[.] ${ }^{31}$

\footnotetext{
${ }^{29}$ Ibid at VII. It is worth mentioning that the foreword is the editors'. It was not written by L. Ron Hubbard. Hubbard is considered the only "source" in Scientology (see e.g. Mikael Rothstein, "Scientology, Scripture and Sacred Traditions," in James R Lewis \& Olav Hammer, eds, The Invention of Sacred Tradition (Cambridge: Cambridge University Press, 2007) 18 at 24.

${ }^{30}$ Hubbard, Introduction to Scientology Ethics, supra note 28 at VII.

${ }^{31}$ Ibid at 308-09.
} 
The description is brief and superficial, likely a testimony to the book's wide public availability. To obtain a full - uncensored, perhaps - description of the law, one must refer to the more detailed policy letters cited in the introduction. ${ }^{32}$ The policy letters and advanced materials can generally be found in two massive sets of volumes, colloquially known to Scientologists ${ }^{33}$ as the "red" (or "tech") and "green" (or "admin") volumes. The red volumes, on the one hand, contain the technical bulletins of Dianetics and Scientology, known as Hubbard Communications Office Bulletins ("HCOBs"). They, broadly, cover Scientology's religious processes and practices. There are two series of volumes: Volumes I to XII, which contain the HCOBs in chronological order and Volumes 1 to 4, which contain specific thematic series of HCOBs. The green volumes, on the other hand, cover the extensive management system created by Hubbard, a system which is mostly relevant to the administration of the religion. The system is described in Hubbard Communications Office Policy Letters ("HCO PLs"). Both sets of books derive their colloquial names from their colour: each book and its ink are, respectively, red and green. The red and green volumes total thousands of pages.

In addition to the sheer magnitude of the information contained in the volumes, the volumes' inaccessibility has contributed to the opacity - notably to scholars and courts - of Scientology's legal system. The church has, ironically, simultaneously expunged the books' existence from its public websites and, at least implicitly, claimed that the books are publicly available. There is, indeed, no mention of the volumes on Scientology's websites. In the Frequently Asked Questions section of its website, the Church states:

The vast majority of Scientology scriptures are widely available to the general public and can be read and studied by anyone. However, a very small portion of the scriptures that deal with the most advanced levels of spiritual counseling is restricted to those parishioners who have attained the prior levels of spiritual awareness.

Scientologists believe that one must be properly prepared-spiritually and ethically-to receive these materials and that premature exposure could impede spiritual development. For this reason, the information in these advanced scriptures is kept confidential.

\footnotetext{
32 See e.g. notes $14,15,17$, and 19 .

${ }^{33}$ See note 1.
} 
The core beliefs of the Scientology religion are publicly available to anyone. These are contained in any one of the eighteen Basic books and accompanying 280 lectures by L. Ron Hubbard available in every Church and mission of Scientology worldwide, as well as public libraries internationally.

$[\ldots]$

It is not unusual for a religion to have confidential scriptures and practices. ${ }^{34}$

The Operating Thetan levels, which constitute the highest levels of spiritual training and counseling within the Church, are confidential. ${ }^{35}$ The passage suggests that these levels are the only confidential scriptures in Scientology, a point which is confirmed by another of the Church's websites. ${ }^{36}$ David S. Touretzky, a professor at Carnegie Mellon University, states on his academic website on Scientology that "[b]oth the red and green volumes may be examined at Scientology churches and are available for sale to the public." ${ }^{37}$ I have found no academic libraries which own copies of the volumes. While the volumes can be ordered (as opposed to bought onsite) from churches of Scientology, they cannot be ordered online from Scientology's publishing arm. Academics or practitioners seeking an understanding of Scientology's legal system would, therefore, need to study the volumes at a local church of Scientology or own a copy. (It is worth pointing out that an academic critical of Scientology would likely be declared "fair game." This would prevent them from acquiring the volumes or entering a church of Scientology to consult them.) While the Basics Books and Lectures are widely accessible, the more detailed materials on Scientology's legal system are much less accessible.

The lack of availability of the materials has left journalists, scholars, and attorneys relying on "leaked" versions which can be found on the Internet. ${ }^{38}$ Although the authenticity of these

\footnotetext{
34 "Frequently Asked Questions: Scientology in Society: Why Does the Church Have Confidential Scriptures?", Scientology, online: <https:/www.scientology.ca/faq/scientology-in-society/why-does-church-have-confidentialscriptures.html>.

35 See note 27.

36 See "White Papers: Scientology Confidential Scriptures", STAND League, online: $<$ https://www.standleague.org/facts-vs-fiction/whitepapers/scientology-confidential-scripture.html > which states, "An extremely small portion (less than one percent) of the Scripture of Scientology is unpublished. These religious materials comprise the most advanced levels of Scientology spiritual counseling." While it is unclear how the Church computed the one percent figure, including the red and green volumes in the confidential scriptures would be inconsistent with the figure.

37 "Scientology's Scripture - The Red and Green Volumes", Dave Touretzky's Page, online: $<$ http://www.cs.cmu.edu/ dst/studytech.org/red_volumes.htm $>$.

${ }^{38}$ See e.g. "English Materials", True Source Scientology Foundation, online: $<$ https://stss.nl/materials/\#> .
} 
leaked versions can be independently verified by comparing them to official versions from private collections and churches of Scientology (as I have done), leaked versions are not as reliable as official versions. This reliability issue causes yet more confusion and may prevent some academics from being able to cite the materials.

This section has explored the materials which constitute Scientology's legal system. The next section addresses the positioning of Scientology's legal system relative to the mainstream legal system.

\section{WITHIN AND WITHOUT}

The relationship of Scientology to the mainstream legal system is complex. This section does not purport to provide a comprehensive overview of the relationship. It will, however, suggest that Scientology does not exist fully without the mainstream legal system. Neither does Scientology solely interact with the legal system when compelled to: the religion voluntarily uses the mainstream legal system (and its institutions) to further its aims - such as the harassment of perceived enemies under the Fair Game law. This fact is not intrinsically inconsistent with the thesis that Scientology's legal system is independent and self-contained. Scientologists only use the mainstream legal system when they feel it can benefit them, not because their legal system needs the mainstream legal system to function.

Acknowledging the existence and understanding the nature of a legal system within a religion is important. Constitutional protections afford significant leeway to religious organisations and their members to act in a way that is consistent with their deeply-held beliefs. ${ }^{39}$ One could not, more broadly, declare oneself exempt from the laws of his country: he would be in breach of legal provisions and subject to sanction. Individuals (and their organisations) can, however, sometimes

\footnotetext{
${ }^{39}$ See e.g. Syndicat Northcrest v Amselem, 2004 SCC 47, [2004] 2 SCR 551, Trinity Western University v British Columbia College of Teachers, 2001 SCC 31, [2001] 1 SCR 772, and Central Alberta Dairy Pool v Alberta (Human Rights Commission), [1990] 2 SCR 489, 72 DLR (4th) 417. In Canada, freedom of religion is protected under section 2 of the Charter of rights and freedoms (CQLR, c C-12). In the United States, it is protected by the first amendment (US Const). See also Dick Anthony \& Thomas Robbins, "Law, Social Science and the 'Brainwashing' Exception to the First Amendment" (1992) 10:1 Behav Sci \& L 5 and Christopher L Eisgruber \& Mariah Zeisberg, "Religious Freedom in Canada and the United States" 4:2 International Journal of Constitutional Law 244. A recent case in the United States upheld an arbitration provision from the Church, under which Scientology ethics rules are applicable (Garcia v Church of Scientology Flag Service Organization, 2018 US Dist LEXIS 119099 (MD Fla).
} 
engage in conduct that is illegal within the mainstream legal system if such conduct is mandated by their religious beliefs. ${ }^{40}$ Constitutional protections for freedom of religion therefore allow legal systems which are unknown to and inconsistent with the mainstream legal system to exist, simultaneously without the mainstream legal system and within the country the latter governs.

Hubbard made clear that he considered the legal system he was devising to be fully independent. The foreword of Introduction to Scientology Ethics states that the book contains "all one needs" to order their lives. ${ }^{41}$ To use, once again, the example of Fair Game law, Hubbard states that once one is declared fair game, he may be "deprived of property or injured by any means by any Scientologist without any discipline of the Scientologist" and "tricked, sued or lied to or destroyed."42 The passage clearly indicates that Scientologists may engage in illegal conduct (within the mainstream legal system), without being disciplined under Scientology's legal system. ${ }^{43}$ Scientology's legal system displaces the rules which exist under the mainstream legal

\footnotetext{
${ }^{40}$ Courts tend to be extremely reluctant to render decisions which could be considered to impede upon the freedom of religion of the individuals involved. As an example, in Headley $v$ Church of Scientology International (687 F (3d) 1173 at III (9th Cir 2012) [Headley]), a United States court found that "claims of psychologically coerced labor [are] barred by the ministerial exception." Interestingly and consistently with its commitment to attack its perceived enemies, Scientology created a website on Marc Headley (one of the plaintiffs in the case), which is quite similar to the website created on Dr. Kent (STAND League, supra note 7). The website reads, in part, as follows:

In a get-rich-quick scheme, Marc and Claire Headley tried filing twin lawsuits against their former Church, seeking millions in damages. Filed to smear the Church in hopes of getting paid off, the Headleys conspired with fellow anti-Scientologists to file complaints with federal officials in an attempt to instigate an investigation on false accusations.

This was supposed to be a "test case" that they hoped would harm the Church. In the end, however, it blew up in their faces. Their salacious allegations and investigation went nowhere, and it was the Headleys and their lawyers who were the losers (Church of Scientology International, "Marc and Claire Headley: Failed Lawsuit/False Claims", Marc and Claire Headley: After Money, online: $<$ http://www.whoismarcheadley.com/> .)
}

Similarly, though the illegality of polygamy has been upheld in Canada (Reference re: Section 293 of the Criminal Code of Canada, 2011 BCSC 1588) and though the relevant provision of the Criminal Code is gender-neutral, the provision has never been used to prosecute a wife and had been used only once to prosecute a husband with multiple wives prior to 2009 (Angela Campbell, "Bountiful Voices" (2009) 47:2 Osgoode Hall LJ 183 at 222). For a critique of the scope of religious freedom, see Marci A Hamilton, God vs the Gavel: Religion and the Rule of Law (Cambridge: Cambridge University Press, 2005).

${ }^{41}$ Hubbard, supra note 28 at VII.

${ }^{42}$ Hubbard, "Penalties for Lower Conditions", supra note 17.

${ }^{43}$ For an example and analysis of Scientologists engaging in illegal conduct, see Urban, "Fair Game", supra note 24. 
system. ${ }^{44}$ Although a detailed exploration of this last point is beyond the scope of this paper, it is worth mentioning Hubbard has suggested that Scientology's legal system may one day replace the mainstream legal system. ${ }^{45}$

While Scientology's legal system is self-contained and independent, Scientology has used the mainstream legal system to further its aims. Under the Fair Game law, the organisation is mandated to use the legal system to harass its perceived enemies. Hubbard states:

The purpose of the suit is to harass and discourage rather than win.

The law can be used very easily to harass, and enough harassment on somebody who is simply on the thin edge anyway, well knowing that he is not authorized, will generally be sufficient to cause professional decease. If possible, of course, ruin him utterly. ${ }^{46}$

The decision to use the mainstream legal system to harass perceived enemies does not suggest that Scientology's legal system needs the mainstream legal system to function.

The next three sections help further the thesis that Scientology's legal system is independent of the mainstream legal system. They, in turn, provide a broad overview of three pillars of the legal system: rules (Section III), enforcement mechanisms (Section IV), and correctional facilities (Section V).

\section{RULES}

The example of the Fair Game law used throughout this paper has provided an example of how rules arise within Scientology's legal system. The rules are in writing, and Scientology

\footnotetext{
${ }^{44}$ See also an essay titled "Justice", where Hubbard suggests that the mainstream legal system is unjust (Freedom Magazine, online: $<\mathrm{https} / /$ www.freedommag.org/english/vol28i2/page48.htm $>$ ) and a comment by Mike Rinder, a former high-ranking executive of the Church, who mentioned that Hubbard considered the latter "corrupt" (Chris Jancelewicz, "7 Shocking Things We Learned from Leah Remini's Scientology Series", Global News (26 January 2017), online: < https://globalnews.ca/news/3207075/7-shocking-things-we-learned-from-leah-reminis-scientologyseries/>.)

${ }^{45}$ See e.g. L Ron Hubbard, "LRH Relationship to Orgs", Hubbard Communications Office Policy Letter, 4 January 1966 ("Somebody some day will say "this is illegal.' By then be sure the orgs [Scientology organisations] say what is legal or not.")

${ }^{46}$ This quotation used to be in the red volumes. It has since been removed, see Fishman, supra note 7 (Exhibit G).
} 
founder L. Ron Hubbard is their only "source." 47 Every rule and principle can be traced back to written materials, and most are found in the "red" (or "tech") and "green" (or "admin") volumes. As stated previously, the red volumes contain the technical bulletins of Dianetics and Scientology, known as Hubbard Communications Office Bulletins ("HCOBs") and the green volumes cover the extensive management system created by Hubbard, as described in Hubbard Communications Office Policy Letters (“HCO PLs"). ${ }^{48}$

There is, interestingly, no codification of the rules of the legal system. While Introduction to Scientology Ethics appears to provide a broad overview of the rules, it is not exhaustive and seems to aim to provide an introductory overview of the legal system, rather than a simplified version of each rule. Adherents are left to study - as much as several hours each day ${ }^{49}$ - the thousands of pages of Scientology volumes to guide their behaviour.

\footnotetext{
${ }^{47}$ Rothstein, supra note 29 at 24.

${ }^{48}$ See Section I, above.

49 The expectations regarding time dedication to studying the scriptures are tacit. Unofficial sources nonetheless suggest that the religion expects significant time dedication. On her blog, a Scientologist states:

By and large, I'd say that Scientologists actively participate a bit more in their religion than many other faiths. By that, I mean that there's a good bit of religious study and counseling that is intrinsic to the faith, and as such it's not uncommon to spend a few days a week in your local church, or even take a few weeks for intensive study every so often. I usually spend 10-12 hours/week in my local church, for example. It generally isn't just a religion where the expectation is that you go to church on Sunday, hear a sermon, and then that concludes your participation. ("How Does the Day-to-Day of Being A Scientologist Compare to Other Religions" (18 December 2017), Scientology Parents: Applying Scientology to Parenting with Results, online: $<\mathrm{http} / /$ www.scientologyparent.com/howdoes-the-day-to-day-of-being-a-scientologist-compare-to-other-religions/> .)
}

Similarly, Leah Remini, a former member, has stated that the religion requires two-and-a-half hours of individual study per day (Chris Jancelewicz, "Leah Remini Reveals What Happens When You Reach the Top of Scientology", Global News (6 September 2017), online: <https://globalnews.ca/news/3721663/leah-remini-scientology-bridge-totalfreedom $>$.) 
Although Hubbard did not consider himself (or act substantially as) a godlike figure, ${ }^{50}$ his pronouncements are similar to the divine commandments found in religious texts. For example, the Ten Commandments read, in part, as follows:

You shall have no other gods before Me.

$[\ldots]$

You shall not murder.

You shall not commit adultery.

You shall not steal.

You shall not bear false witness against your neighbor.

You shall not covet your neighbor's wife; and you shall not desire your neighbor's house, his field, his male servant, his female servant, his ox, his donkey, or anything that is your neighbor's.

These words the Lord spoke to all your assembly, in the mountain from the midst of the fire, the cloud, and the thick darkness, with a loud voice; and He added no more. And He wrote them on two tablets of stone and gave them to me. ${ }^{51}$

The Hubbard Communications Office Policy Letter on suppressive acts (cited previously) reads, in part, as follows:

Due to the extreme urgency of our mission, I have worked to remove some of the fundamental barriers from our progress.

The chief stumbling block, huge above all others, is the upset we have with potential trouble sources and their relationship to suppressive persons or groups.

$[\ldots]$

A suppressive person or group is one that actively seeks to suppress or damage Scientology or a Scientologist by suppressive acts.

\footnotetext{
${ }^{50}$ Scientology has stated that Hubbard was not similar to Jesus Christ and that he "personally stated he was a man as others are men" and "was a much-loved friend and teacher and continues to be respected and loved" ("Frequently Asked Questions: Founder: Do Scientologists Believe that L. Ron Hubbard Was Like Jesus Christ", Scientology, online: $<$ https://www.scientology.ca/faq/scientology-founder/do-scientologists-believe-that-l-ron-hubbard-was-likejesus-christ.html > .) Although a full analysis of Scientology's conception of God is beyond the scope of this paper, Scientologists believe in exaltation, the process through which the believer himself is deified (see e.g. Donald A Westbrook, "Researching Scientology and Scientologists in the United States: Methods and Conclusions" in James R Lewis, ed, Handbook of Scientology (Leiden: Brill, 2017).) Members of the Church of Jesus Christ of Latter-Day Saints hold a similar belief. The Church's website summarises the concept as follows: "When we lived with our Heavenly Father, He explained a plan for our progression. We could become like Him, an exalted being" ("Exaltation", The Church of Jesus Christ of Latter-Day Saints, online: < https://www.lds.org/manual/gospel-principles/chapter-47exaltation?lang=eng $>$.)

${ }^{51}$ The Bible (London, UK: Fireside Bible Publishers, 1999), Deuteronomy 5:6-22.
} 
Suppressive acts are acts calculated to impede or destroy Scientology or a Scientologist and which are listed at length in this policy letter.

[...]

[S] uppressive acts include:

Any felony (such as murder, arson, etc.) against person or property.

Sexual or sexually perverted conduct contrary to the well-being or good state of mind of a Scientologist in good standing or under the charge of Scientology, such as a student or a preclear.

Blackmail of Scientologists or Scientology organizations threatened or accomplished - in which case the crime being used for blackmail purposes becomes fully outside the reach of Ethics and is absolved by the fact of blackmail unless repeated.

Using the trademarks and service marks of Dianetics and Scientology without express permission or license from the owner of the marks or its authorized licensee.

Falsifying records.

Testifying or giving data against Scientology falsely or in generalities or without personal knowledge of the matters to which one testifies. ${ }^{52}$

The full list encompasses many pages. I do not address in great depth how the passage could be read as incorporating the mainstream legal system through a reference to felonies. No specific legal reference is made, and felonies are not specific to a single legal system. The reference is, therefore, consistent with the thesis that Scientology's legal system fully displaces the mainstream legal system. There are similarities between the Ten Commandments and the Policy Letter. Both list crimes without offering individual justifications. Both use the first person and an assertive tone.

The rules in Scientology's legal system, unlike those in the mainstream legal system, are frozen in time and the product of a single source. ${ }^{53}$ While the legislative process in liberal democracies is defined by its debates and consensuses, Scientology's legal system does not benefit from debate. With Hubbard as the single source, the body of rules is, further, prevented from

\footnotetext{
52 Hubbard, "Fair Game Law 2", supra note 15. The same passage is reproduced (without reference) in Introduction to Scientology Ethics, supra note 28 at 308-310.

53 A counter-example is The Church of Jesus Christ of Latter-Day Saints, which has altered some of its doctrines in the face of changing societal attitudes, see Bush, supra note 20. The same can be said of Jehovah's Witnesses, see George Chryssides, "How Prophecy Succeeds: Jehovah's Witnesses and Prophetic Expectations" (2010) 1:1 International Journal for the Study of New Religions 29 and Edmond C Gruss, Jehovah's Witnesses: Their Claims, Doctrinal Changes, and Prophetic Speculation: What Does the Record Show? (Maitland: Xulon, 2007) at 218.
} 
evolving over time to meet unforeseen or unforeseeable challenges and adapt to a changing world. The survival of a legal system may depend on its ability to change with the world in which it exists. Other religious legal systems are, by definition, similar to Scientology's legal system. The Sharia was, for instance, posited thousands of years ago. It has nonetheless been actualised through incrementally modernising statutes $^{54}$ and juridical interpretation. ${ }^{55}$ Scientology's rules and institutions do not allow for such modernisation.

The materials that constitute Scientology's legal system provide a full set of rules to guide every aspect of the life of the religion's members. The next section provides an overview of another pillar of the legal system: its enforcement mechanisms.

\section{ENFORCEMENT MECHANISMS}

Scientology's legal system also includes enforcement mechanisms. This section briefly summarises the "Committee of Evidence", which appears to be the enforcement mechanism used in all cases where a rule is breached.

The foundational enforcement mechanism for the system of "ethics, justice, and law" 56 devised in Scientology materials is the Committee of Evidence. The Committee of Evidence, often referred to as Comm Ev, ${ }^{57}$ is Scientology's tribunal. Once a member is accused of breaching a "rule

\footnotetext{
${ }^{54}$ See e.g. Ann Elizabeth Mayer, "Law: Modern Legal Reform" in John L Esposito, ed, The Oxford Encyclopedia of the Islamic World (Oxford: Oxford University Press, 2009), online:

$<$ http://www.oxfordislamicstudies.com/article/opr/t236/e0473>, which states:

\begin{abstract}
Reforms affecting Islamic law in the nineteenth and twentieth centuries were more far-reaching than any undertaken previously. The impetus for reform came both from within the Islamic tradition, as specialists in Islamic law sought to reform laws in the face of changing attitudes and social needs, and from without, as political leaders imposed changes designed to eliminate archaic features that impeded governmental modernization programs.
\end{abstract}

${ }^{55}$ Intisar A Rabb, "Law. Civil Law \& Courts" in John L Esposito, ed, The Oxford Encyclopedia of the Islamic World (Oxford: Oxford University Press, 2009), online: <http://www.oxfordislamicstudies.com/article/opr/t236/e0473> .

${ }^{56}$ See e.g. Introduction to Scientology Ethics, supra note 28 at VII ("Scientologists and, indeed, the whole of Mankind are extremely fortunate to have, for the first time in history, a practical system of Ethics and Justice based solely on reason") and Hubbard, "Fair Game Law 1", supra note 14. I, as stated in Section I, refrain from commenting on the use of these words.

${ }^{57}$ See e.g. Hubbard, "Administration Outside Scientology", supra note 16 ("If the Internal Revenue Service continues to act up or if the FDA does sue we can of course Comm Ev them and if found guilty, label and publish them as a Suppressive Group and fair game [them].") 
of ethics" or a "law," the local organisation's "LRH Communicator" convenes the Committee of Evidence, which includes a chairman, a secretary, and two to five members whose rank is higher than the "accused"'s. ${ }^{58}$ Within a two-week period, the committee is presented the evidence. The accused is not represented by a lawyer or a person fulfilling a substantially similar role. ${ }^{59}$ The Committee then issues its "Findings and Recommendations" document, which includes their finding of guilt on each count (determined by majority vote). The recommendations include punishment, in keeping with L. Ron Hubbard policy. ${ }^{60}$ If the member is dissatisfied with the outcome, they can request a new Committee of Evidence, which reviews the documentation and issues their own "Findings and Recommendations."61 The member may also petition for cancellation of the Committee of Evidence. The petition is reviewed by a high-ranking member or a full Committee of Evidence, following the process detailed previously. ${ }^{62}$

It is worth mentioning that there are no public records which would suggest whether Hubbard policy is indeed applied as written. The next section provides an overview of the last pillar of Scientology's legal system: its correctional facilities.

\section{CORRECTIONAL FACILITIES}

Scientology's legal system further includes correctional facilities. Correctional facilities are the last pillar of an independent legal system: once rules have been broken and a judgment has been rendered, the subject is punished.

\footnotetext{
${ }^{58}$ L Ron Hubbard, "Injustice”, Hubbard Communications Office Policy Letter, 24 February 1972.

${ }^{59}$ L Ron Hubbard, "Evidence, Admissibility of in Hearings, Boards or Committees", Hubbard Communications Office Policy Letter, 17 July 1966.

60 L Ron Hubbard, "Committees of Evidence, Scientology Jurisprudence, Administration of", Hubbard Communications Office Policy Letter, 7 September 1963 [Hubbard, "Committees”].

61 See Hubbard, "Injustice", supra note 58; Hubbard, "Committees", ibid; and L. Ron Hubbard, "Concerning Committees of Evidence", Hubbard Communications Office Policy Letter, 22 September 1963.

62 See Hubbard, "Injustice", supra note 58; Hubbard, "Committees", supra note 61; and Hubbard, "Concerning Committees of Evidence", ibid. For a broader analysis of Scientology’s ethics system, see Roger Straus, "Scientology 'Ethics': Deviance, Identity and Social Control in a Cult-Like Social World" (1986) 9:1 Symbolic Interaction 67.
} 
To state that the correctional facilities in post-Hubbard ${ }^{63}$ Scientology have been of significant interest to the media and to popular culture would be an understatement. Much of the attention has been on The Hole, a Scientology facility situated on Scientology's Gold Base (an estate owned by the Church where Church management resides and works) and created circa 2004 by leader David Miscavige. ${ }^{64}$ The facility has been described as prison-like by former members. Having met with "a dozen former members of the church's religious order, the Sea Org" and relying on the court testimony of Debbie Cook, ${ }^{65}$ a former high-ranking Scientologist, journalists from the Tampa Bay Times state:

[The Hole] became a place of confinement and humiliation where Scientology's management culture - always demanding - grew extreme. Inside, a who's who of Scientology leadership went at each other with brutal tongue lashings, and even hands and fists. They intimidated each other into crawling on their knees and standing in trash cans and confessing to things they hadn't done. They lived in degrading conditions, eating and sleeping in cramped spaces designed for office use.

All were ministers, members of the Sea Org. ${ }^{66}$

The Hole, which has occupied a significant place in public discourse in recent years, is not described in Hubbard's writings. It appears to be part of the broader correctional institution within the Church, the "Rehabilitation Project Force." The phrase refers to the practice of making

63 Hubbard passed away in 1986 ("L. Ron Hubbard", Encyclopaedia Britannica, online: $<$ https://www.britannica.com/biography/L-Ron-Hubbard $>$.)

${ }^{64}$ Janet Reitman, Inside Scientology: The Story of America's Most Secretive Religion (Boston: Houghton Mifflin Harcourt, 2011) at 339.

${ }^{65}$ Cook was the captain (head) of the Flag Land Base (Scientology's "mecca," where the religion's most advanced services are offered). When Cook left the religion, circa 2011, she mass-sent an email criticising the Church. Scientology sued Cook and later settled out of court. Cook had the opportunity to testify in a pre-trial hearing. While the public record is not available online, a section of the hearing can be accessed on YouTube ("Church of Scientology Flag Service Organization vs Debbie Cook" (14 September 2013), online: $<$ https://www.youtube.com/watch?v=AqTp-szDdeU> .) Cook's email can be accessed on certain blogs (see e.g. "Debbie Cook's Email", supra note 14). The case is Church of Scientology International v Debbie Cook.

66 "Scientology Defectors Describe Violence, Humiliation in "The Hole" (12 January 2013), online: $<$ http://www.tampabay.com/news/scientology/scientology-defectors-describe-violence-humiliation-in-the-

hole/1270047> . I, again, rely on the account of former members. While Scientology may claim that these former members are "disgruntled liars" (see e.g. Lawrence Wright, "What Happens When You Try to Leave the Church of Scientology?", The Guardian (23 April 2011), online: <https://www.theguardian.com/world/2011/apr/23/try-to-leavechurch-scientology-lawrence-wright>), current members refuse to comment on this topic and would likely deny the existence of the facility if they did. 
members engage in manual labour while studying the works of L. Ron Hubbard. This institution was devised by Hubbard circa 1969. Hubbard was then at sea on a Church-owned ship, surrounded by loyal followers and managing the organisation. The early version of the Rehabilitation Project Force involved "specific recommendations which if followed [would] rehabilitate the individual as a highly effective and worthwhile Sea Org member." ${ }^{67}$ He describes it as follows:

[T] he unit is worked hard during the day on a rigorous schedule on jobs assigned by the Review Chief handling corrective areas and jobs needing remedy and repair. The Unit itself is thus made into an effective ship's review team. It works on a one job, one time, one place formula completing each job before moving into the next. Each individual thus earns the right to the remedial services he or she will receive [referring to religious services]. ${ }^{68}$

The institution has outlived Hubbard. There seem to be no other correctional facilities described by Hubbard.

\footnotetext{
${ }^{67}$ L Ron Hubbard, "Rehabilitation Unit", Flag Order 1848, 3 March 1969. A flag order is a binding document written by L. Ron Hubbard, similar to a policy letter.

${ }^{68}$ Ibid. Also see generally Stephen Kent, "Brainwashing in Scientology's Rehabilitation Project Force (RPF) (Paper delivered at the Society for the Scientific Study of Religion, San Diego, 7 November 1997) [unpublished]; Stephen A Kent, "Brainwashing Programs in The Family/Children of God and Scientology" in Thomas Robbins \& Benjamin Zablocki, eds, Misunderstanding Cults: Searching for Objectivity in a Controversial Field (Toronto: University of Toronto Press, 2000) 349; Lorne L Dawson, "Raising Lazarus: A Methodological Critique of Stephen Kent's Revival of the Brainwashing Model" in Thomas Robbins \& Benjamin Zablocki, eds, Misunderstanding Cults: Searching for Objectivity in a Controversial Field (Toronto: University of Toronto Press, 2000) 379; Stephen A Kent, "Compelling Evidence: A Rejoinder to Lorne Dawson's Chapter” in Thomas Robbins \& Benjamin Zablocki, eds, Misunderstanding Cults: Searching for Objectivity in a Controversial Field (Toronto: University of Toronto Press, 2000) 401; and J Gordon Melton, “A Contemporary Ordered Religious Community: The Sea Organization” (2018) 2:2 J CESNUR 21.
} 


\section{CONCLUSION}

This paper has sought to provide a broad overview of the legal system of the religion of Scientology. Section I analysed the sources from which Scientology's legal system arises; Section II analysed the latter's position relative to the mainstream legal system; and Sections III, IV, and $\mathrm{V}$ provided an overview of three pillars of the legal system: rules, enforcement mechanisms, and correctional facilities.

This paper will, I hope, simultaneously have provided an underpinning for a nascent field of academic research and a demystification of a complex yet fascinating legal system. The scope of Scientology's legal system and the volume of its constitutive materials offer grounding for a field of research of significant breadth and depth. They allow and, I would argue, require rigorous analysis. If we know where to find the rules that constitute Scientology's legal system, we should not rely on Scientology to tell us what these rules are. Courts and practitioners had, thus far, lacked an objective overview of Scientology's legal system and its constitutive materials. They were left to navigate, with little time, a maze of materials. In research and in adjudication, rigour is fundamental. Each day, there are individuals being "fair gamed" or otherwise harmed. Their protection depends on an understanding of Scientology's legal system.

The media and, more broadly, public discourse will always afford Scientology the opportunity to tell its (side of the) story. They will, similarly, always have a special place for sensationalism and criticism, and for Scientology's detractors. A balanced conversation especially on complex issues at the crossroads of law and religion - is, however, not a mere conversation between opposing sides. A balanced conversation requires input from more objective, disinterested parties. A conversation without scholars, without rigorous analysis, is one where much is said and argued but little is understood. We need more facts, more rigorous analyses, and fewer, more grounded opinions.

The potential for future research is significant. Scientology's legal system is, in many ways, an embodiment of its founder's personality. It is a reminder of the risks inherent to giving a single individual absolute control. The legal system magnifies individual tendencies to seek maximal control, suppress dissent, and project one's way of thinking onto the other. It also acts as a powerful way for the founder's persona (embodied by L. Ron Hubbard's initials $L R H$ ) to outlive the founder himself, allowing the latter to exert control over the religion's members far beyond his 
natural life. ${ }^{69}$ Legal systems are exceedingly powerful. They can define enemies, create urgency, and channel a group's energy. To fully understand groups and individuals, we must understand the legal systems that guide their behaviour.

${ }^{69}$ On this point, see generally Susan Raine, "Surveillance in New Religious Movements: Scientology as a Case Study" (2009) 28:1 Religious Studies Theology 63. 


\section{BIBLIOGRAPHY}

\section{LEGISLATION}

Charter of rights and freedoms, CQLR, c C-12, s 2.

US Const amend I.

\section{JURISPRUDENCE}

Central Alberta Dairy Pool v Alberta (Human Rights Commission), [1990] 2 SCR 489, 72 DLR (4th) 417.

Church of Scientology v Armstrong, 232 Cal (3d) 1060 (App Ct 1991).

Church of Scientology v Fishman and Geertz, 35 F (3d) 570 (9th Cir 2012).

Garcia v Church of Scientology Flag Service Organization, 2018 US Dist LEXIS 119099 (MD Fla).

Headley v Church of Scientology International, 687 F (3d) 1173 (9th Cir 2012).

Hill v Church of Scientology of Toronto, [1995] 2 SCR 1130, 126 DLR (4th) 129.

$R v$ Church of Scientology of Toronto (1997), 33 OR (3d) 65, 34 WC (2d) 453 (CA).

Reference re: Section 293 of the Criminal Code of Canada, 2011 BCSC 1588.

Religious Technology Center v Netcom On-Line Communication Services, 907 F Supp 1361 (ND Cal 1995).

Religious Technology Center v Lerma, 908 F Supp 1353 (ED Va 1995).

Syndicat Northcrest v Amselem, 2004 SCC 47, [2004] 2 SCR 551.

Trinity Western University v British Columbia College of Teachers, 2001 SCC 31, [2001] 1 SCR 772.

Wollersheim v Church of Scientology, 212 Cal (3d) 872 (App Ct 1989).

\section{SECONDARY MATERIALS: ADVANCED SCIENTOLOGY SCRIPTURES}

Hubbard, L Ron. “Administration Outside Scientology”, Hubbard Communications Office Policy Letter, 2 April 1965.

—. "Cancellation of Fair Game", Hubbard Communications Office Policy Letter, 21 October 1968.

-. "Committees of Evidence, Scientology Jurisprudence, Administration of", Hubbard Communications Office Policy Letter, 7 September 1963.

—. "Concerning Committees of Evidence", Hubbard Communications Office Policy Letter, 22 September 1963. 
—. "Ethics Protection", Hubbard Communications Office Policy Letter, 1 September 1965.

—. "Evidence, Admissibility of in Hearings, Boards or Committees", Hubbard Communications Office Policy Letter, 17 July 1966.

—. "Injustice”, Hubbard Communications Office Policy Letter, 24 February 1972.

—. "LRH Relationship to Orgs", Hubbard Communications Office Policy Letter, 4 January 1966.

—. "Penalties for Lower Conditions", Hubbard Communications Office Policy Letter, 18 October 1967.

_. "Rehabilitation Unit", Flag Order 1848, 3 March 1969.

-. "Suppressive Acts - Suppression of Scientology and Scientologists - The Fair Game Law", Hubbard Communications Office Policy Letter, 1 March 1965.

-. "Suppressive Acts - Suppression of Scientology and Scientologists - The Fair Game Law", Hubbard Communications Office Policy Letter, 23 December 1965.

\section{SECONDARY MATERIALS: ARTICLES}

Anthony, Dick \& Thomas Robbins. "Law, Social Science and the 'Brainwashing' Exception to the First Amendment" (1992) 10:1 Behav Sci \& L 5.

Campbell, Angela. "Bountiful Voices” (2009) 47:2 Osgoode Hall LJ 183.

Chryssides, George. "How Prophecy Succeeds: Jehovah's Witnesses and Prophetic Expectations" (2010) 1:1 International Journal for the Study of New Religions 29.

Eisgruber, Christopher L \& Mariah Zeisberg. "Religious Freedom in Canada and the United States" 4:2 International Journal of Constitutional Law 244.

Estéveza, Estefanía, Marina Rachitskiyb \& Carla Rodríguez. "Is Perception of the Mainstream Legal System Homogeneous Across Ethnic Groups?” (2013) 5:2 European Journal of Psychology Applied to Legal Context 155.

Fitzpatrick, Kathy R \& Maureen Shubow Rubon. "Public Relations vs. Legal Strategies in Organizational Crisis Decisions” (1995) 21:1 Public Relations Review 21.

Griffiths, Casey Paul, Scott C Esplin \& E Vance Randall. “'The Glory of God Is Intelligence': Exploring the Foundations of Latter-day Saint Religious Education” (2016) 111:2 Religious Education 153.

Horwitz, Paul. "Scientology in Court: A Comparative Analysis and Some Thoughts on Selected Issues in Law and Religion” (1997) 47:1 DePaul L Rev 85.

Introvigne, Massimo. "Did L. Ron Hubbard Believe in Brainwashing?: The Strange Story of the 'Brain-Washing Manual' of 1955” (2017) 20:4 Nova Religio: The Journal of Alternative and Emergent Religions 62.

Kent, Stephen. "The Creation of 'Religious' Scientology" (1999) 18:2 Religious Studies and Theology 97. 
—. "Narconon, Scientology, and the Battle for Legitimacy" (2017) 19:1 Marburg Journal of Religion 1.

Kent, Stephen A. “Scientology - Is this a Religion?” (1999) 4:1 Marburg Journal of Religion 1.

—. "Scientology's Relationship with Eastern Religious Traditions" (1996) 11:1 Journal of Contemporary Religion 21.

-. "The Globalization of Scientology: Influence, Control and Opposition in Transnational Markets" (1999) 29 Religion 147.

— \& Terra A Manca. "A War Over Mental Health Professionalism: Scientology Versus Psychiatry" (2009) 12 Mental Health Religion \& Culture 1.

Kumar, JP. “'Fair Game': Leveling the Playing Field in Scientology Litigation” (1997) 16:1 Rev Litig 747.

Melton, J Gordon. "A Contemporary Ordered Religious Community: The Sea Organization" (2018) 2:2 J CESNUR 21.

Raine, Susan. "Surveillance in New Religious Movements: Scientology as a Case Study" (2009) 28:1 Religious Studies \& Theology 63.

Urban, Hugh B. "Fair Game: Secrecy, Security, and the Church of Scientology in Cold War America" (2006) 74:2 Religion and Secrecy 356.

—. "The Third Wall of Fire"” (2017) 20:4 Nova Religio: The Journal of Alternative and Emergent Religions 13.

Straus, Roger. "Scientology 'Ethics': Deviance, Identity and Social Control in a Cult-Like Social World" (1986) 9:1 Symbolic Interaction 67.

Westbrook, Donald A. “'The Enemy of My Enemy Is My Friend': Thomas Szasz, the Citizens Commission on Human Rights, and Scientology's Anti-Psychiatric Theology" (2017) 20:4 Nova Religio: The Journal of Alternative and Emergent Religions 37.

\section{SECONDARY MATERIALS: COLLECTIONS OF ESSAYS}

Bush, Jr, Lester E. "Mormonism's Negro Doctrine: An Historical Overview" in Lester E Bush, Jr \& Armand L Mauss, eds, Neither White nor Black: Mormon Scholars Confront the Race Issue in a Universal Church (Midvale: Signature Books, 1984) at 70.

Cowan, Douglas E \& David G Bromley. "The Church of Scientology" in Eugene V Gallagher \& W Michael Ashcraft, eds, Introduction to New and Alternative Religions in America (Wesport CT: Greenwood, 2006) 169.

Dawson, Lorne L. "Raising Lazarus: A Methodological Critique of Stephen Kent's Revival of the Brainwashing Model" in Thomas Robbins \& Benjamin Zablocki, eds, Misunderstanding Cults: Searching for Objectivity in a Controversial Field (Toronto: University of Toronto Press, 2000) 379.

Holly, Marylin. "Navajo Criminal Justice: A Jungian Perspective” in Jeffrey Ian Ross \& Larry 
Allen Gould, eds, Native Americans and the Criminal Justice System (Boulder: Paradigm, 2006) 17.

Kent, Stephen. "Scientology's Harassment of Stephen A Kent, September 1997 - November 2001" in Herbert C Northcott, ed, A History of the Department of Sociology at the University of Alberta 61, online: $\quad<$ https://era.library.ualberta.ca/items/5d96e454-6177-49a4-b3a37a9e7a7cbcf1/view/cf9ca389-f480-4e20-ba61cd790f5dc171/01022018_History_of_Dept_Sociology_UAlberta.pdf>.

Kent, Stephen A. "Brainwashing Programs in The Family/Children of God and Scientology" in Thomas Robbins \& Benjamin Zablocki, eds, Misunderstanding Cults: Searching for Objectivity in a Controversial Field (Toronto: University of Toronto Press, 2000) 349.

-. "Compelling Evidence: A Rejoinder to Lorne Dawson's Chapter" in Thomas Robbins \& Benjamin Zablocki, eds, Misunderstanding Cults: Searching for Objectivity in a Controversial Field (Toronto: University of Toronto Press, 2000) 401.

Mayer, Ann Elizabeth. "Law: Modern Legal Reform" in John L Esposito, ed, The Oxford Encyclopedia of the Islamic World (Oxford: Oxford University Press, 2009), online: $<$ http://www.oxfordislamicstudies.com/article/opr/t236/e0473> .

Rothstein, Mikael. "Scientology, Scripture and Sacred Traditions," in James R Lewis \& Olav Hammer, eds, The Invention of Sacred Tradition (Cambridge: Cambridge University Press, 2007) 18.

Rabb, Intisar A. "Law. Civil Law \& Courts" in John L Esposito, ed, The Oxford Encyclopedia of the Islamic World (Oxford: Oxford University Press, 2009), online: $<$ http://www.oxfordislamicstudies.com/article/opr/t236/e0473> .

Westbrook, Donald A. "Researching Scientology and Scientologists in the United States: Methods and Conclusions" in James R Lewis, ed, Handbook of Scientology (Leiden: Brill, 2017).

\section{SECONDARY MATERIALS: MONOGRAPHS}

Cooper, Paulette. The Scandal of Scientology (New York: Belmont-Tower, 1972).

von Dehsen, Christian D. ed, Lives \& Legacies: An Encyclopedia of People Who Changed the World: Philosophers and Religious Leaders (Oryx: Phoenix, 1999).

Flowers, Ronald B. Religion in Strange Times: The 1960s and 1970s (Macon, GA: Mercer University Press, 1984).

Greenawalt, Kent. Religion and the Constitution (Princeton: Princeton University Press, 2008).

Gruss, Edmond C. Jehovah's Witnesses: Their Claims, Doctrinal Changes, and Prophetic Speculation: What Does the Record Show? (Maitland: Xulon, 2007).

Hamilton, Marci A. God vs the Gavel: Religion and the Rule of Law (Cambridge: Cambridge University Press, 2005).

Holden, Andrew. Jehovah's Witnesses: Portrait of a Contemporary Religious Movement (New 
York: Routledge, 2002).

Hubbard, L Ron. Dianetics: The Modern Science of Mental Health, revised ed (Los Angeles: Bridge, 2007).

—. Introduction to Scientology Ethics, revised ed (Los Angeles: Bridge, 2007).

—. Scientology: The Fundamentals of Thought, revised ed (Los Angeles: Bridge, 2007).

Lewis, James R. Scientology (Oxford: Oxford University Press, 2009).

Miller, Russel. Bare-Faced Messiah: The True Story of L. Ron Hubbard (Toronto: Key Porter, 1987).

Ortega, Tony. The Unbreakable Miss Lovely: How the Church of Scientology Tried to Destroy Paulette Cooper (Kidderminster: Silvertail, 2015).

Reitman, Janet. Inside Scientology: The Story of America's Most Secretive Religion (Boston: Houghton Mifflin Harcourt, 2011).

Rosenoer, Jonathan. CyberLaw: the Law of the Internet (New York: Springer, 1996).

The Bible (London, UK: Fireside Bible Publishers, 1999).

Wallis, Roy. The Road to Total Freedom: A Sociological Analysis of Scientology (New York: Columbia University Press, 1977).

Wright, Lawrence. Going Clear: Scientology, Hollywood, and the Prison of Belief (New York: Albert A Knopf, 2013).

\section{SECONDARY MATERIALS: NEWSPAPERS, NEWSWIRES, AND OTHER NEWS SOURCES}

"15 Million Member Milestone Announced at Church's General Conference: President Monson, President Uchtdorf Remark on Church Growth" (5 October 2013), The Church of Jesus Christ of Latter-day Saints: Newsroom, online: <https://www.mormonnewsroom.org/article/15-millionmember-milestone-announced-at-churchs-general-conference $>$.

Cannane, Steve \& Brigid Andersen. "How the Church of Scientology Tried to Bring Down Journalist Paulette Cooper, aka Miss Lovely", $A B C$ News (21 December 2016), online: $<$ http://www.abc.net.au/news/2015-07-17/how-scientology-tried-to-bring-down-misslovely/6627782>.

Grace, Gillian. “Anderson Cooper to Scientology's David Miscavige: 'It's On"” (28 March 2010), The National Post, online: < https://nationalpost.com/news/anderson-cooper-to-scientologysdavid-miscavige-its-on> .

Jancelewicz, Chris. "7 Shocking Things We Learned from Leah Remini's Scientology Series", Global News (26 January 2017), online: < https://globalnews.ca/news/3207075/7-shocking-thingswe-learned-from-leah-reminis-scientology-series/> .

Jancelewicz, Chris. "Leah Remini Reveals What Happens When You Reach the Top of 
Scientology", Global News (6 September 2017), online:

$<$ https://globalnews.ca/news/3721663/leah-remini-scientology-bridge-total-freedom/> .

Jarvik, Elaine. "Scientology: Church Now Claims More than 8 Million Members" (20 September 2004), Deseret Morning News, online:

$<$ https://web.archive.org/web/20080616032022/http://deseretnews.com/dn/view/0\%2C1249\%2C $595091823 \% 2 \mathrm{C} 00 . \mathrm{html}>$.

Leiby, Richard. “John Travolta's Alien Notion”, The Washington Post (28 November 1999), online: <http:/www.washingtonpost.com/wp-

dyn/content/article/2005/07/06/AR2005070601403.html?nav=rss_metro/religion> .

Nocera, Joe. "Scientology's Chilling Effect" (24 February 2015), The New York Times, online: $<$ https:/www.nytimes.com/2015/02/24/opinion/joe-nocera-scientologys-chilling-effect.html $>$.

Sappell, Joel \& Robert W Welkos. "The Man in Control”, The Los Angeles Times (24 June 1990), online: <http://www.latimes.com/local/la-scientologysideb062490-story.html > .

Sappell, Joel \& Robert W Welkos. "On the Offensive Against an Array of Suspected Foes", The Los Angeles Times (29 June 1990), online: <http://www.latimes.com/local/la-scientology062990xstory.html>.

"Scientology Defectors Describe Violence, Humiliation in 'The Hole"“, The Tampa Bay Times (12 January 2013), online: <http://www.tampabay.com/news/scientology/scientology-defectorsdescribe-violence-humiliation-in-the-hole/1270047> .

Tobin, Thomas C. 'Pervasive Pitch: Scientology Book and Lecture Series, 'The Basics,' Unleashes a Sales Frenzy", The Tampa Bay Times (13 November 2011), online: < https://www.tampabay.com/news/scientology/pervasive-pitch-scientology-book-and-lectureseries-the-basics-unleashes-a/1201177> .

Wright, Lawrence. "What Happens When You Try to Leave the Church of Scientology?", The Guardian (23 April 2011), online: <https://www.theguardian.com/world/2011/apr/23/try-to-leavechurch-scientology-lawrence-wright $>$.

\section{SECONDARY MATERIALS: OTHERS}

“2017 Service Year Report of Jehovah's Witnesses Worldwide: 2017 Grand Totals”, Jehovah's Witnesses: Publications, online: <https://www.jw.org/en/publications/books/2017-service-yearreport/2017-grand-totals/> .

Behar, Richard. "The Prophet and Profits of Scientology" (27 October 1986), Forbes, online: $<$ https://www.cs.cmu.edu/ dst/Fishman/forbes-behar.html $>$.

"Bigotry \& Hate Exposed: Stephen Kent", STAND League, online: $<$ https://www.standleague.org/bigotry-and-hate/exposed/stephen-kent.html $>$.

"Church of Scientology Flag Service Organization vs Debbie Cook" (14 September 2013), online: YouTube $<$ https://www.youtube.com/watch?v=AqTp-szDdeU $>$. 
Church of Scientology International. "Marc and Claire Headley: Failed Lawsuit/False Claims", Marc and Claire Headley: After Money, online: <http://www.whoismarcheadley.com/> .

"Copyright and Trademark Notice", Scientology, online:

$<$ https://www.scientology.org/copyright.html $>$.

"David Miscavige", Religious Technology Center: Holder of the Dianetics and Scientology Trademarks, online: <http://www.rtc.org/david-miscavige.html> .

"David Miscavige: Scientology Scripture Recovered and Restored in 25-Year Program Completed in 2009", Scientology, online: <https://www.scientology.org/david-miscavige/renaissance-forscientology/completion-of-the-golden-age-of-knowledge.html $>$.

"Debbie Cook's Email" (5 March 2013), Scientology Cult: "A Time Comes When Silence is Betrayal”, online: $<$ http://www.scientology-cult.com/debbie-cooks-email.html $>$.

"English Materials", True Source Scientology Foundation, online: <https://stss.nl/materials/\#>.

"Exaltation", The Church of Jesus Christ of Latter-Day Saints, online: < https://www.lds.org/manual/gospel-principles/chapter-47-exaltation?lang=eng> .

"Frequently Asked Questions: Founder: Do Scientologists Believe that L. Ron Hubbard Was Like Jesus Christ", Scientology, online: < https://www.scientology.ca/faq/scientology-founder/doscientologists-believe-that-l-ron-hubbard-was-like-jesus-christ.html> .

"Frequently Asked Questions: What is Church of Scientology International?", Scientology, online: $<$ https://www.scientology.ca/faq/church-management/what-is-church-of-scientologyinternational.html> .

"Frequently Asked Questions: What Is the State of Clear?", Scientology, online: $<$ https://www.scientology.ca/faq/clear/what-is-the-state-of-clear.html $>$.

"Frequently Asked Questions: What Is Meant by Operating Thetan?", Scientology, online: $<$ https://www.scientology.ca/faq/operating-thetan/what-is-ot.html $>$.

"Frequently Asked Questions: What Is The Bridge In Scientology?", Scientology, online: $<$ https:/www.scientology.ca/faq/background-and-basic-principles/what-is-the-bridge-inscientology.html $>$.

"Frequently Asked Questions: Scientology in Society: Why Does the Church Have Confidential Scriptures?", Scientology, online: <https:/www.scientology.ca/faq/scientology-in-society/whydoes-church-have-confidential-scriptures.html $>$.

Graham, Ruth. “Are Academics Afraid to Study Scientology?” (5 November 2014), JSTOR Daily, online: $<$ https://daily.jstor.org/scholars-on-scientology/> .

"How Does the Day-to-Day of Being A Scientologist Compare to Other Religions" (18 December 2017), Scientology Parents: Applying Scientology to Parenting with Results, online: $<$ http://www.scientologyparent.com/how-does-the-day-to-day-of-being-a-scientologist-compareto-other-religions/ $>$.

Hubbard, L Ron. "Justice”, Freedom Magazine, online:

$<$ https://www.freedommag.org/english/vol28i2/page48.htm> . 
"Introduction: Global Humanitarian Initiatives \& Affiliated Social Betterment Programs Supported by the Church of Scientology", Scientology, online: < https:/www.scientology.org/how-wehelp.html>.

Jacobsen, Jonny. "Counting Scientology: Reality Check: Independent Data Contradicts Scientology's Membership Claims” (9 February 2017), Medium, online: $<$ https://medium.com/how-many-scientologists-are-there-really/5-factoring-in-reality$3 \mathrm{f} 0 \mathrm{bb} 2 \mathrm{~d} 4 \mathrm{e} 4 \mathrm{cf}>$.

Kent, Stephen. "Brainwashing in Scientology's Rehabilitation Project Force (RPF) (Paper delivered at the Society for the Scientific Study of Religion, San Diego, 7 November 1997) [unpublished].

"L. Ron Hubbard", Encyclopaedia Britannica, online:

$<$ https://www.britannica.com/biography/L-Ron-Hubbard $>$.

"L. Ron Hubbard: Founder of Dianetics and Scientology", Scientology, online: $<$ https://www.scientology.org/l-ron-hubbard/> .

"Leah Remini: Scientology and the Aftermath: About", $A \& E$, online: $<$ https://www.aetv.com/shows/leah-remini-scientology-and-the-aftermath/about> .

McDonell-Parry, Amelia. "5 Things We Learned From 'Scientology and the Aftermath,' Episode 2", Rolling Stone, online: <https:/www.rollingstone.com/tv/tv-news/5-things-we-learned-fromscientology-and-the-aftermath-episode-2-104842/> .

"Missions \& Aims of BYU”, BYU, online: <http://aims.byu.edu/> .

"Scientology's Scripture - The Red and Green Volumes", Dave Touretzky's Page, online: $<$ http://www.cs.cmu.edu/ dst/studytech.org/red_volumes.htm> .

"The Basics", Bridge Publications, online: <http://www.bridgepub.com/introduction/thebasics.html> .

"The Bridge to Total Freedom", online:

$<$ http://www.whatisscientology.org/html/Part02/Chp06/img/grdchart.gif $>$.

"What Are the Abrahamic Religions?: Christianity, Islam, and Judaism Are Regarded as the Largest Abrahamic Religions by the Number of Adherents", World Atlas, online: $<$ https:/www.worldatlas.com/articles/what-are-the-abrahamic-religions.html $>$.

"White Papers: Scientology Confidential Scriptures", STAND League, online: $<$ https://www.standleague.org/facts-vs-fiction/whitepapers/scientology-confidentialscripture.html>. 